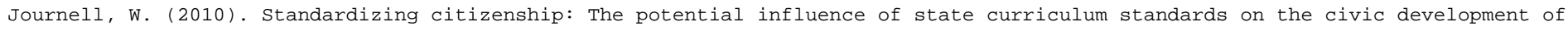
adolescents. PS: Political Science \& Politics, 43, 351-358.

Made available courtesy of Oxford University Press: http://dx.doi.org/10.1017/S1049096510000272

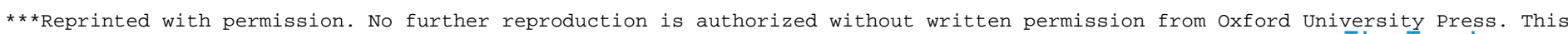

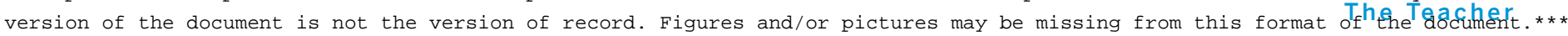

\title{
Standardizing Citizenship: The Potential Influence of State Curriculum Standards on the Civic Development of Adolescents
}

Wayne Journell, University of North Carolina at Greensboro

ABSTRACT The rise of state-mandated standards in public education have allowed legislators to answer the question of what constitutes a proper civic education, a debate that has existed in the United States since the turn of the twentieth century. Through the content they employ in their standards, states may indirectly influence the type of citizenship education students receive in the classroom. The present study focuses on the Virginia Standards of Learning for two courses, civics and economics and U.S. and Virginia government, which are commonly taught to eighth graders and high school seniors, respectively. A content analysis of the essential knowledge found in the standards for these courses categorizes instructional content into seven forms of citizenship: civic republicanism, character education, deliberative, social justice, participatory, transnational, and cosmopolitan. Although the results are specific to the Virginia Standards of Learning, the nature of how citizenship is portrayed within the standards may transfer to other states with similar forms of standards-based education within their social studies curricula.

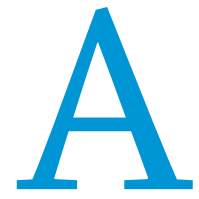

$\mathrm{n}$ extensive body of literature within political science suggests that political socialization starts in the primary grades and continues throughout life (Sapiro 2004; Easton and Dennis 1967). Using Foucault's (1991) notion of governmentality, interpersonal relationships and societal institutions aid in this socialization, and their influence varies from individual to individual. Moreover, it has become commonplace to acknowledge the role of family (Achen 2002) and public schooling (Callan 1997; Dewey 1916; Gutmann 1987) in developing the civic identities of individuals within American society. Therefore, even when approaching political socialization from a developmental perspective (Merelman 1971), studying the role of schooling in the formulation of students' political identities seems apt, given that maturation of political thought corresponds with the time students spend within the confines of public education.

Yet, Macedo et al. argue that schools "often teach about citizenship and government without teaching students the skills that are necessary to become active citizens themselves" (2005, 33). Even in civics and government courses, which Kahne, Chi, and

Wayne Journell is an assistant professor of secondary social studies education at the University of North Carolina at Greensboro. His research focuses on the teaching of politics and citizenship in high school social studies classrooms. He can be reached at wayne_journell@uncg.edu.
Middaugh describe as "the part of the formal high school curriculum that is most explicitly linked to the democratic purposes of education" (2006, 391), conversations about citizenship rarely extend beyond one's right to vote. Recent movements to standardize public education in the United States have only exacerbated this notion by mandating content taught to students. Although the social sciences fall outside the realm of No Child Left Behind (NCLB), many states have standardized their civics and government curricula as part of the sweeping trend toward greater teacher accountability and systemized decision making.

Virginia was one of the first states to introduce curriculum standards, even prior to the implementation of No Child Left Behind, and its Standards of Learning (SOLs) have been subsequently used as a model for standardization efforts in other states. In this study, I analyze the content of the Virginia SOLs for civics and economics and U.S. and Virginia government, which are commonly taught to eighth graders and high school seniors, respectively. Although a study of the way that one state promotes citizenship within its standards does not necessarily generalize to how citizenship is portrayed in other states or even in Virginia public schools, it does show the potential of states to frame the meaning of citizenship within standards. The specific questions addressed are: (a) What type of citizenship do the civics and government SOLs advocate? (b) How do the civics and government 
SOLs differ? (c) How well do the civics and government SOLs provide students with knowledge of citizenship that allows them to function as able participants in a democratic society?

\section{THE IMPACT OF STANDARDS AND HIGH-STAKES TESTING ON TEACHER PRACTICES}

Curriculum standards are nothing new to public education. Since the evolution of the American public school system in the eighteenth century, local school districts have provided guidelines to teachers regarding appropriate content for classroom instruction. However, since the 1983 publication of A Nation at Risk (National Commission on Excellence in Education), public education in the United States has adopted a neoliberal approach that calls for states to mandate high-stakes testing components aligned to instructional standards in order to theoretically ensure that students learn the same knowledge and skills, regardless of the school or district in which they reside (Hursh 2007). Therefore, to place this study within its proper context, the Virginia Department of Education mandates that the same civics and government standards be taught to all eighth and twelfth grade students, respectively, throughout the Commonwealth.

Although teachers still maintain autonomy over their classrooms, there is considerable evidence to suggest that curriculum standards coupled with a high-stakes testing component impact teachers' instructional decision making. Research on social studies teachers in states that annually assess student knowledge has found that teachers do not necessarily change their instructional strategies in the wake of increased accountability, but they do appear to focus their instruction on curricular material that will be included in an end-of-course assessment (Grant 2001; Segall 2003; van Hover 2006; van Hover and Pierce 2006; Vogler 2005). In other words, increased teacher accountability seems to foster a teach-to-the-test mentality, even if teachers do not make a conscious effort to create such an environment in their classroom.

Although multiple criticisms of high-stakes testing have been made, the one of particular interest to this study is that standards, like textbooks, are social constructions based on the ideology and values of an elite minority (Apple 1979; Apple 2007). As one might expect, the loudest objections to mandated curricula often occur when states attempt to dictate an absolute stance on value-laden concepts such as citizenship, patriotism, politics, evolution, or cultural history. ${ }^{1}$ In particular, the questions of how schools define who is considered to be a citizen and what entails proper citizenship within a society have fostered considerable political unrest and occasional violence both within the United States and throughout the rest of the world (Ahonen 2001; Al-Haj 2005; Banks 1990; Gordon 2005; Hofman 2007; LaSpina 2003; Pike 2007). For example, in her case study of the Virginia social studies SOL adoption process, Fore (1998) chronicles the ideological divisiveness between liberals who advocated inclusive standards that promoted a wide range of civic ideals and the conservative administration of then-governor George Allen that sought to perpetuate traditional notions of citizenship.

In the following section, I will explore the various citizenship discourses prevalent in public education throughout the United States. I will then critically analyze the Virginia SOLs for civics and government based on these discourses in an attempt to discern the underlying civic messages being sent to students enrolled in these courses. Finally, I will use these findings to discuss implications for public school students in Virginia and draw general conclusions about the role that standards play in the civic responsibility of public education.

\section{FORMS OF CITIZENSHIP USED IN PUBLIC EDUCATION}

A considerable amount of literature in political science has chronicled waning democratic participation in the United States since the 1970s, with various explanations given for the decline (Delli Carpini and Keeter 1996; Hibbing and Theiss-Morse 2002; Macedo et al. 2005; Putnam 2000). However, one constant within studies on citizenship is the acknowledgement that formal education plays an integral role in the development of civic ideals. Nie, Junn, and Stehlik-Barry (1996) view formal education as the predominant indicator of political activity among citizens, particularly when considering levels of education as relative to other individuals within the population. However, few studies on citizenship attempt to explain why the correlation between formal education and active citizenship exists or even offer explicit standards of what individuals should know to competently participate in a democracy (Kuklinski and Quirk 2001).

In their preeminent study of civic knowledge in the United States, Delli Carpini and Keeter (1996) argue that all citizens should have a basic familiarity with three broad categories of civic knowledge to rationally participate in a democratic society. The first is what they call the "rules of the game," or general democratic processes of governance. Second is substantive knowledge of politics, such as current issues, policy initiatives, and foreign relations. Finally, they state that people should know key political individuals and possess basic knowledge of political parties. The authors argue that maintaining this base set of knowledge allows for greater trust in government and increased consistency of public opinion.

These categories represent broad themes of civic knowledge, however, and provide little guidance for teachers on exactly what knowledge to convey in their classrooms. Patrick (2006) developed a pedagogical framework for educating students about the American democratic system, which includes the democratic processes outlined by Delli Carpini and Keeter, as well as knowledge of natural rights and the qualifications and responsibilities associated with citizenship. Patrick also identifies the need to educate public school students on the importance of communitarian aspects of citizenship, such as membership in voluntary associations and community involvement, which aligns with the work of political scientists who advocate for an increase in social capital as a way to encourage democratic participation (Putnam 200o). Finally, Patrick believes that students should possess a basic understanding of capitalism and the forces that drive the American market economy.

However, the civic knowledge that students receive throughout their time in public education rarely correlates with these recommendations. When asked for examples of good citizenship, students tend to emphasize character traits, such as helping others and obeying laws, rather than political activities such as voting or protesting (Chiodo and Martin 2005; Hickey 2002; Martin and Chiodo 2007). Moreover, Niemi and Junn (1998) found that although high school students appear to possess basic understandings of divisions of government and rights of citizens, students tend to know relatively little about politics or informal governmental practices such as lobbying.

Yet, educators continue to debate the merits of various types of civic education in the belief that lessons learned in public education are instrumental to the development of a politically aware and active citizenry (Dewey 1916). In the following sections, I will 
define the most prominent civic discourses present in social studies curricula throughout the United States. These discourses will then serve as the basis for my critique of the Virginia SOLs.

\section{Civic Republicanism and Character Education}

Within public schooling, the responsibility for civic education often falls to the social studies (Ross 2006). Debates have raged within social studies over the proper way to teach citizenship, and several discourses have received considerable attention within the literature. Perhaps the most prevalent citizenship discourse in American public education, which has received renewed emphasis since the terrorist attacks of September 11, 2001, is that of civic republicanism (Knight Abowitz and Harnish 2006). Those who advocate civic republicanism emphasize a common national ethos, a position that has gained momentum in the wake of poor student performances on standardized tests of historical knowledge (Ravitch and Finn 1987). Proponents of civic republicanism also view schools as encouraging cooperation between citizens and government and citizen participation in the political process (Butts 1988; Damon 2001). According to civic republican thought, schools should purvey patriotic values. Students should support the actions of their countries and learn the skills necessary to compete and succeed in the political economy (Butts 1988; Damon 2001; Ravitch 2006). Not surprisingly, in times of national or international turmoil, educators often resort to a civic republican curriculum to provide stability and comfort for their students (Knight Abowitz and Harnish 2006).

Despite widespread use of civic republicanism throughout the United States, scholars have attacked the discourse as being politically assimilatory, particularly during times of war and global conflict (Westheimer 2006). Ben Porath (2003) refers to this ultranationalist stance as "belligerent citizenship," which produces undesirable side effects such as unquestioning political loyalty and social alienation of minority groups. Such thinking has led educators to question the relationship between public schools and the state, and to ask whether advocacy of an emotion-laden, patriotic curriculum provides the most valuable educational experience for students entering an increasingly pluralistic society (Nash 2005).

Closely related to civic republicanism is the concept of character education. While civic republicanism identifies personal character as essential to citizenship, those advocating character education view the development of student morality as superior to nationalist doctrine (Farr Darling 2002; Noddings 1988). Forms of character education have existed since the early 1800 , largely to inculcate local morality in students (Leming 2001). Today, however, advocates of character education view the teaching of basic morals as a way to bridge the gap between polarizing cultures and beliefs (Holmes 2001). Character education proponents view social studies as "a special kind of moral education built on a foundation of ethical commitments that are required for a democratic, pluralistic society" (Farr Darling 2006, 267). In other words, the same moral fibers that make good people will, in turn, produce good citizens, leading to a civilized, productive society.

Multiple objections exist to pure character education. Critics argue that discussions of morality should take place at home, and that any discussion of morality in school manipulates and imposes values on students (Farr Darling 2006). Critics also suggest that morality varies by culture; however, others argue that basic values of humanity span cultural differences (Farr Darling 2006; Gut- mann 2004). Kahne and Westheimer (2006) suggest that character education often obscures the prominence of political and societal influences on social problems by placing too much emphasis on the agency of moral individuals. They argue that students must understand the value of working within the political system in order to achieve reform. Despite these objections, proponents of character education view public schools as providing a necessary function by impressing basic moral values on students who may fail to receive them otherwise.

\section{Liberal Citizenship Discourses}

What I refer to as "liberal" citizenship discourses serve as the antithesis to civic republicanism and character education. Liberal views of citizenship focus on political deliberation, questioning of authority, and social diversification (Gutmann 1987). In addition, liberal forms of citizenship do not prescribe any one doctrine, preferring to allow individuals the right to define their own views of morality and patriotism. However, while all notions of a liberal civic education deplore the belligerent byproducts of uncontrolled civic republicanism, not all liberal discourses portray the same epistemological view of citizenship.

Perhaps the most utilized form of liberal citizenship is what Gutmann and Thompson (2004) term deliberative democracy, which encourages public discourse on policy and controversial issues. They outline principles of reciprocity, accountability, liberty, and opportunity as the cornerstones of deliberative citizenship and argue that each is essential for citizens living in a pluralistic society. Ben Porath (2003) argues that teachers should particularly use deliberation in times of conflict to limit the aforementioned effects of belligerent citizenship. According to Ben Porath, deliberation acts as a form of patriotism, in that the primary goal of citizenship is to continually seek to better one's country, even if such a goal means recognizing societal and governmental imperfections. Therefore, he states that ensuring that leaders are held accountable is one of the most important actions an informed citizenry can undertake.

Critics of deliberative citizenship argue that deliberation stifles political agency, because exposure to divergent viewpoints has been found to discourage civic action. However, the same studies have shown that deliberation raises tolerance toward diverse political opinions (Mutz 2006). Another criticism of deliberative democracy is that it strikes at the heart of the nationalistic goals of civic republicanism, because deliberative citizens can publicly disagree with the will of the majority, even after extensive deliberation. Critics argue that such thinking leads to the type of divisive society that obstructs domestic progress and weakens American influence abroad (Knight Abowitz and Harnish 2006). Proponents of deliberative citizenship respond to such criticism by acknowledging that deliberation is perpetual and occasionally prone to mistakes. However, in the event of political error, further deliberation allows for appropriate corrective measures (Gutmann and Thompson 2004).

Two similar forms of classroom citizenship that utilize deliberation are social justice and participatory models. Proponents of social justice encourage students to seek out and discuss elements of societal injustice and oppression, often of traditionally marginalized groups, with the goal of fostering social change (Ayers 1998). Vinson (2006), citing Young (1992), identifies five types of oppression found in society: exploitation, marginalization, powerlessness, cultural imperialism, and violence. Vinson argues that civic 
education should combine knowledge of these social ills with student political and societal involvement.

Closely related to social justice is what Westheimer and Kahne $(1998 ; 2004)$ call a participatory form of citizenship. After instructing students in skills of civic engagement, such as public speaking, awareness, and diligence, teachers should encourage student participation in political and social issues, particularly in students' local communities. After observing multiple social studies programs that offer students opportunities for civic participation, the authors note several attributes that lead to positive civic experiences for students. For example, classes that allow students to engage in real-world projects and place students within a community of fellow participants appear to foster student agency on social issues (Westheimer and Kahne 1998; Kahne and Westheimer 2004; Kahne and Westheimer 2006). Moreover, recent studies have found that participating in community service during high school acts as a predictor of adult voting and volunteering (Hart et al. 2007; Kahne and Sporte 2008). Both social justice and participatory discourses adhere to a conception of citizenship in which schools are central fixtures within democratic society and teachers must address societal problems as well as advocate student agency for societal improvements (Ayers 1998; Counts 1932; Rugg 1933).

Transnational, or global, citizenship education also encourages student agency, but on an international scale. Proponents of transnational citizenship believe that curriculum should emphasize the increasing economic, social, and cultural globalization of nation-states (Knight Abowitz and Harnish 2006). This requires abandoning the traditional Eurocentric curriculum in favor of multicultural studies that force students to critically challenge their preexisting values and worldviews (Merryfield and Subedi 2006). Perhaps most central to transnational citizenship is the emphasis on the United States as a leader of international policy, with a goal of encouraging students to make connections between their local communities and issues of global importance (Myers 2006).

Closely related to transnationalism is cosmopolitanism, which views compassion, cooperation, and peace as universal virtues of all people living in a global society (Knight Abowitz and Harnish 2006). Thus, proponents seek to teach students that certain environmental, economic, and social issues transcend geopolitical boundaries, and that, as members of the global community, they have the responsibility to raise awareness and actively engage themselves within the scope of these issues (Hicks 2003). In short, advocates for cosmopolitanism view individuals as world citizens who share a desire to address and eliminate problems relating to all humanity, such as environmental pollution, human rights abuses, and genocide (Ahmad and Szpara 2005).

Despite the stark differences among many of these various discourses, the version of citizenship presented within public education rarely falls completely into a particular category. In the remainder of this article, I will examine the extent to which each of these discourses is presented within the Virginia SOLs for civics and U.S. government. I will then discuss the implications of this analysis for secondary students in Virginia, as well as make general comments about the nature of state standards and civic education.

\section{METHODS}

To better understand the potential of state standards to frame citizenship, I engaged in a qualitative, or interpretive, content analysis (Krippendorff 2004) of the Virginia SOLs for both civics and government. ${ }^{2}$ This method is appropriate for a subjective topic like citizenship, because no standard categories for analysis exist, and investigators often have to develop categories based on existing ideas or themes (Holsti 1969). However, for the purposes of this study, it should be noted that only civics is annually tested by the Commonwealth. Virginia does not currently require statewide assessment of its government curriculum because of the assessment's close proximity to student graduation.

As part of the analysis, I coded the essential knowledge in each standard and substandard based on the various citizenship discourses previously mentioned. ${ }^{3}$ In doing so, I used the various discourses collectively as a framework in which I assigned value to each element of essential knowledge to reduce the data into a manageable form and posit conclusions (LeCompte and Schensul 1999). Hence, Ilabeled proposing patriotism, focusing on influential texts or people in American history, advocating a continuation of the American way of life, or simply describing structural processes of American government as civic republican standards. Standards dealing with character or moral issues I delegated as such. I categorized standards as deliberative that hinted at value judgments or articulating personal opinions on issues. I labeled elements of the curriculum that mentioned oppression, liberation from oppression, or structures of government that promote equality as social justice. I labeled all standards that encouraged student activism as participatory. Finally, Ilabeled any standards that mentioned international issues as transnational, unless they advocated spreading American values abroad (civic republican) or explicitly mentioned attempts at world peace or human rights, which I then categorized as cosmopolitan. Occasionally, I came across standards that focused entirely on historical or economic information that did not fall into any of the previously discussed citizenship discourses. These standards were given their own category and not included in the analysis.

\section{RESULTS}

Table 1 shows the number of civics standards that fell into each category, with examples of the type of standards found in each.

When taken together, civic republicanism and character education compose nearly $60 \%$ of the civics standards. The greatest amount of content in the civics framework focuses on the structure and processes of American government, although civic republicanism can also be found in repeated references to civic responsibility and patriotism. For example, standards CE.3c and CE.3d both focus on the duties of good citizens, and CE.4e explicitly lists practicing patriotism as a virtue of good citizenship. Linked to these civic republican ideals are character traits the Commonwealth describes as aiding the facilitation of citizenship, such as trustworthiness, honesty, and self-reliance. Other character traits involve skills that will allow students to compete in a market economy, such as maintaining a strong work ethic.

Much of the remaining content fits into a more liberal definition of citizenship, although the various forms of liberal citizenship are not represented equally within the civics standards. Comparatively, the Commonwealth places greater value on student participation in both their communities and the democratic process. Standard CE.3d encourages students to engage in democratic actions such as voting, communicating with elected officials, and participating in political campaigns. Students are then encouraged in CE.3e to aid their communities by volunteering, becoming involved in public service organizations, and expressing general concern about the welfare of the community as a whole. 


\begin{tabular}{|c|c|c|}
\hline TYPE OF CITIZENSHIP & $\begin{array}{l}\text { NUMBER OF } \\
\text { STANDARDS }\end{array}$ & EXAMPLES OF STANDARDS \\
\hline Civic Republicanism & 28 & $\begin{array}{l}\text { CE.3c Describing the duties of citizenship, including obeying the law, paying taxes, defending the nation, and } \\
\text { serving in court } \\
\text { CE.4e Practicing patriotism } \\
\text { CE.6c Explaining the principle of separation of powers and the operation of checks and balances }\end{array}$ \\
\hline Character Education & 6 & $\begin{array}{l}\text { CE.4a Practicing trustworthiness and honesty } \\
\text { CE.4d Practicing respect for the law }\end{array}$ \\
\hline Deliberative & 5 & $\begin{array}{l}\text { CE.5b Comparing the similarities and differences of political parties } \\
\text { CE.7c Examining the impact of the media on public opinion and public policy }\end{array}$ \\
\hline Social Justice & 5 & $\begin{array}{l}\text { CE.8d Explaining how due process protections seek to ensure justice } \\
\text { CE.11e Describing the protection of consumer rights and property rights }\end{array}$ \\
\hline Participatory & 10 & $\begin{array}{l}\text { CE.3d1 Examining the responsibilities of citizenship, including registering and voting } \\
\text { CE.3d4 Examining the responsibilities of citizenship, including serving in voluntary, appointed positions }\end{array}$ \\
\hline Transnational & 1 & $\begin{array}{l}\text { CE.10d Examining the relationship of Virginia and the United States to the global economy, with emphasis on the } \\
\text { impact of technological innovations }\end{array}$ \\
\hline Cosmopolitan & 0 & $\mathrm{n} / \mathrm{a}$ \\
\hline None of the Above & 2 & $\begin{array}{l}\text { CE.8b Describing the exercise of judicial review } \\
\text { CE.9a Applying the concepts of scarcity, resources, choice, opportunity cost, price, incentives, supply and demand, } \\
\text { production, and consumption }\end{array}$ \\
\hline
\end{tabular}

Despite the emphasis on active participation, societal reasons for participation are discussed less frequently. Social justice in the civics standards predominantly focuses on understanding how the structure of government supports differing viewpoints and secures justice for all within society, regardless of race, gender, or socioeconomic status. An equal amount of time is spent on student deliberation. The standards encourage students to question traditional, yet expanding aspects of government, such as media influences, political polarization, and the cost of elections.

Issues of international importance receive scant attention in the civics standards. The only way that the standards situate the United States as a member of a global community is through economic interdependence. The standards omit other aspects of international relations, such as treaties and membership in global agencies. Moreover, the standards appear devoid of any cosmopolitan influences, ignoring concepts such as human rights at home or abroad, or attempts at securing world peace in times of global conflict.

Table 2 shows the distribution of content in the government standards. In contrast to civics, civic republicanism and character education only make up $46 \%$ of the government standards. Yet, civic republicanism represents the largest concentration of content within government, with a focus on the processes of democratic government. However, references to patriotism and guidelines on how to contribute to the American market economy permeate the standards. In addition, the same basic elements of character education present in civics also appear in the government standards.

The percentage of the government standards that fits within a liberal conception of citizenship is greater than that of civics, and the distribution among the various liberal citizenship forms varies between the two courses as well. Although the overall amount of content that is considered social justice or deliberative increases in the government standards, the percentage of content that falls within those two forms of citizenship is com- parable to the civics standards. Moreover, the topics that utilize social justice and deliberative conceptions of citizenship appear roughly the same between the two sets of standards, with the Government standards focusing on the processes that ensure equality among citizens and deliberation of current governmental issues. The government standards also begin to address differences in ways to conceptualize governmental actions and ask students to debate the merits of liberal and conservative views on government.

Where the government and civics standards truly differ is in the way the former handles participatory citizenship and introduces a global element into the curriculum. The government standards are less likely to advocate student action, both within the community and the democratic process. The government standards tend to define participation broadly and encourage students to become more active politically, while the civics standards often list specific ways for students to contribute. For example, the government standards do not advocate for students to join voluntary associations or participate in community events.

However, the government standards do situate the United States within an international sphere. More government content is considered transnational compared to any other of the liberal views of citizenship used in this analysis. The standards include an entire section on foreign policy, ranging from safeguarding the global environment to international efforts to curb drug trafficking. The standards also place the United States within the global economy and provide basic understanding of how global economic trends impact domestic economic decisions. Although the majority of the economics section of the government standards deals with how the American market economy functions, the standards frame the discussion within a global context. Finally, standard GOVT.13 asks students to compare the government and economy of the United States with those of Mexico, Great Britain, and China. 
Table 2

Government Standards, Grouped by Form of Citizenship

\begin{tabular}{lcl} 
TYPE OF CITIZENSHIP & $\begin{array}{l}\text { NUMBER OF } \\
\text { STANDARDS }\end{array}$ & \\
\hline Civic Republicanism & 37 & $\begin{array}{l}\text { GOVT.4b Identifying the purposes of government stated in the Preamble } \\
\text { GOVT.17e Practicing patriotism } \\
\text { GOVT.18a Obeying the law and paying taxes }\end{array}$ \\
\hline Character Education & 5 & $\begin{array}{l}\text { GOVT.17a Practicing trustworthiness and honesty } \\
\text { GOVT.17c Practicing responsibility, accountability, and self-reliance }\end{array}$ \\
\hline Deliberative & 9 & $\begin{array}{l}\text { GOVT.5d Examining the ongoing debate that focuses on the balance of power between state and national } \\
\text { governments } \\
\text { GOVT.6d Analyzing the influence of media coverage, campaign advertising, and public opinion polls } \\
\text { GOVT.9a Examining different perspectives on the role of government }\end{array}$ \\
\hline Social Justice & 10 & $\begin{array}{l}\text { GOVT.11a Examining the Bill of Rights, with emphasis on First Amendment freedoms } \\
\text { GOVT.11e Explaining every citizen's right to be treated equally under the law }\end{array}$ \\
\hline Participatory & $\begin{array}{l}\text { GOVT.9d Describing how individuals, interest groups, and the media influence public policy } \\
\text { GOVT.18c Participating in the political process } \\
\text { GOVT.18e. Keeping informed about public issues }\end{array}$ \\
\hline Transnational & $\begin{array}{l}\text { GOVT.12a Describing the responsibilities of the national government for foreign policy and national security } \\
\text { GOVT.13a Demonstrate how governments in Mexico, Great Britain, and China compare with government in the } \\
\text { United States } \\
\text { GOVT.15f Analyzing global economic trends }\end{array}$ \\
\hline Cosmopolitan & $\begin{array}{l}\text { GOVT.12b1 Fulfilling a commitment to preserve a peaceful world } \\
\text { GOVT.12b3 Protecting nations from aggression }\end{array}$ \\
\hline None of the Above & $\begin{array}{l}\text { GOVT.2d Explaining the guarantee of rights set forth by the Virginia Company of London } \\
\text { GOVT.14e Examining productivity and standard of living as measured by key economic indicators }\end{array}$ \\
\hline
\end{tabular}

Although the government standards include relatively few examples of a cosmopolitan view of citizenship, the inclusion of these examples does represent an increase from the civics standards. When dealing with foreign policy, the government standards list efforts to secure peace and rid the world of human rights violations. The standards designate the United States as a protector of less advantaged peoples, calling for the nation to intervene in the event of unprovoked aggression on a sovereign state. Finally, the standards identify the United States as central to reducing the number of nuclear and biological weapons throughout the world.

While much of the content between the two courses overlaps, the focus of the civics and U.S. government standards do differ slightly, as one would expect. For example, the government standards use a historical framework to create a context for a detailed analysis of the Constitution, while the civics standards tend to focus on American democracy in its present form. Yet, the standards for the two courses also differ in the way they treat certain elements of citizenship beyond the differences listed previously. When considering the responsibilities and duties of good citizenship, both standards list obeying laws, paying taxes, and voting. Yet, only the civics standards list registering for and serving in the armed forces if called upon as a duty of citizenship. Similarly, only the civics standards encourage students to join voluntary associations and engage in community service.

Even when considering the most basic act of citizenship, each set of standards provides a different focus. Both standards encourage students to register and vote, but only the civics standards actually provide students with instructions on how to register to vote in Virginia. The government standards instead focus on the problem of nonvoting and list several reasons why people choose not to vote. The government standards also explain the processes for national elections in detail, including how voter participation is affected by governmental institutions such as the Electoral College.

Of course, these examples only represent the standards of two courses within the social studies curriculum of a single state. What lessons, then, can this analysis offer about the nature of state standards and civic education? More important, how should secondary civics and government teachers approach state standards when trying to develop curricula designed to promote citizenship in their classrooms?

\section{CONCLUSIONS}

Perhaps the most salient conclusion drawn from this study is that standards, like textbooks and other educational materials, are created to perpetuate a certain ideological position (Apple 1979). Over a decade later, the SOLs still maintain a largely conservative approach to citizenship that harkens back to the political climate surrounding the creation of the standards (Fore 1998). Although liberal civic elements can be found in both the civics and government curricula, they do little to alter the civic republican perspective found throughout each of the standards. Although I would argue that it is not the responsibility of politicians or educational policymakers to push a certain ideology in the classroom, the nature of government-mandated standards suggests that neutrality is impossible to achieve. 4 Therefore, educators need to be cognizant of imbalances within the curriculum and frame their instruction so that their students receive a balanced version of citizenship and democracy.

The fact-based nature of standards also lends itself to a simplistic approach to civic understanding. As seen in the SOLs, standards place emphasis on institutional structure and governmental processes, resulting in knowledge that correlates with Delli Carpini 
and Keeter's (1996) findings in the general population. Moreover, the structure of the standards rarely allows for in-depth discussions of theoretical or ideological concepts such as patriotism or civic responsibility.

Again, teachers need to recognize the static nature of standards and frame their instruction accordingly. Recent studies have found that social studies classrooms rarely utilize discussion, and scholars often point to standards-based education as a contributing factor (Parker 2006; Wilen 2003). The SOLs contain few standards designed to stimulate discussion; therefore, teachers must act on their own to foster the ideals of deliberation in their classrooms. A similar argument can be made for participatory and social justice aspects of citizenship. The ubiquitous nature of standards prohibits specific recommendations for active or communitarian aspects of citizenship. It is the responsibility of educators to encourage students to participate in democracy in order to develop the habits associated with active citizenship, rather than to simply reap its benefits as passive spectators (Kahne and Westheimer 2004; Macedo et al. 2005).

Finally, educators need to ensure that their instruction is age appropriate, even when the curriculum fails to do so. The lack of emphasis on voting in the government SOL represents a poor pedagogical decision on behalf of the state. Given the perennial low voter turnout among young Americans (Campbell 2005; Lopez, Kirby, and Sagoff 2005), teachers should reinforce the reasons for regularly voting at all stages of the educational process, but particularly as students reach adulthood and are in the process of leaving state-mandated schooling. Informing students of the processes of voter registration in the eighth grade, but not in their senior year, seems especially ill-conceived. Discussions on the importance of informed voting should be common practice for all high school juniors and seniors, along with the provision of detailed instructions on how and where to register.

A similar argument can be made for participatory aspects of citizenship. Older students are primed for instruction on how to involve themselves in social or political issues at the local, state, and national levels, while younger students often lack the opportunity to make substantive contributions. Instilling the ethics of voluntary participation at a young age may plant the seeds for civic participation later in life, but older students need constant reminders, particularly as their political and social convictions evolve and strengthen.

Most educators agree that schools need to prepare students for civic life, but differences in ideology make this requirement a complicated endeavor. Although standards vary from state to state, one aspect remains common: teachers will use state standards as guidelines for instruction. Therefore, an understanding of the type of citizenship a state advocates will allow educators to compensate for partisan or ideological imbalances found within the formal curriculum. Because no perfect set of standards exist, educators must implement changes at the classroom level to ensure that students receive a balanced view of citizenship. By exposing students to different perspectives of citizenship, educators can better achieve the goal of developing well-rounded citizens who will positively contribute to our democratic society. "

\section{NOTES}

1. For examples of such arguments, refer to Apple 2008; Banks 1990; Hess 2004; LaSpina 2003; Westheimer 2007.
2. The Virginia SOLs can be accessed through the Virginia Department of Education website. The civics standards can be found at http://www.doe.virginia.gov/ VDOE/Instruction/History/curriculum_framework_2001/hist_7.pdf and the government standards at http://www.doe.virginia.gov/VDOE/Instruction/ History/curriculum_framework_2001/hist_12.pdf.

3. Although one can often see a stark difference between civic republican and liberal citizenship discourses, the lines between various liberal discourses often blur. For example, social justice and participatory aspects of citizenship are often complimentary and hard to distinguish from each other. Therefore, standards that are categorized as pertaining to a particular liberal discourse could potentially be interpreted differently by others. The goal of the analysis was not necessarily to rigidly categorize each standard, but rather to develop a general sense of the type of citizenship that is advocated in the civics and U.S government standards.

4. Even though my personal feelings on civic education contradict much of the civic republican agenda, I would argue that standards that unfairly advocate liberal versions of citizenship also pose a risk to students.

\section{REFERENCES}

Achen, Christopher H. 2002. "Parental Socialization and Rational Party Identification." Political Behavior 30: 151-70.

Ahmad, Iftikhar, and Michelle Y. Szpara. 2005. "Education for Democratic Citizenship and Peace: Proposal for a Cosmopolitan Model.” Educational Studies 38: 8-23

Ahonen, Sirkka. 2001. "Politics of Identity through History Curriculum: Narratives of the Past for Social Exclusion-or Inclusion?" Journal of Curriculum Studies 33: 179-94.

Al-Haj, Majid. 2005. "National Ethos, Multicultural Education, and the New History Textbooks in Israel." Curriculum Inquiry 35: 47-71.

Apple, Michael W. 1979. Ideology and Curriculum. London: Routledge \& Kegan Paul.

. 2007. "Ideological Success, Educational Failure? On the Politics of No Child Left Behind. Journal of Teacher Education 58: 108-116.

. 2008. "Education Versus Creationism in Education. Educational Policy 22: 327-35.

Ayers, William. 1998. "Popular Education-Teaching for Social Justice." In Teaching for Social Justice: A Democracy and Education Reader, ed. William Ayers, Jean Ann Hunt, and Therese Quinn, xvii-xxv. New York: Teachers College Press.

Banks, James A. 1990. "Citizenship Education for a Pluralistic Democratic Society." The Social Studies 81: 210-14.

Ben Porath, Sigal R. 2003. "War and Peace Education." Journal of Philosophy of Education 37: 525-33.

Butts, R. Freeman. 1988. "The Moral Imperative for American Schools: '... Inflame the Civic Temper ...'” American Journal of Education 96: 162-94.

Callan, Eamonn. 1997. Creating Citizens: Political Education and Liberal Democracy. Oxford, UK: Oxford University Press.

Campbell, David E. 2005. "Vote Early, Vote Often: The Role of Schools in Creating Civic Norms." Education Next 5 (3): 63-69.

Chiodo, John J., and Leisa A. Martin. 2005. "What Do Students Have to Say About Citizenship? An Analysis of the Concept of Citizenship among Secondary Education Students." Journal of Social Studies Research 29: 23-31.

Counts, George S. 1932. Dare the School Build a New Social Order? New York: John Day.

Damon, William. 2001. "To Not Fade Away: Restoring Civil Identity Among the Young." In Making Good Citizens: Education and Civil Society, ed. Diane Ravitch and Joseph P. Viteritti, 122-41. New Haven, CT: Yale University Press.

Delli Carpini, Michael X., and Scott Keeter. 1996. What Americans Know About Politics and Why It Matters. New Haven, CT: Yale University Press.

Dewey, John. 1916. Democracy and Education. New York: Free Press.

Easton, David, and Jack Dennis. 1967. "The Child's Acquisition of Regime Norms: Political Efficacy." American Political Science Review 61: 25-38.

Farr Darling, Linda. 2002. "The Essential Moral Dimensions of Citizenship Education: What Should We Teach?" Journal of Educational Thought 36: 229-47.

. 2006. "Teaching Social Studies as if It Mattered: Young Children and Moral Deliberation." In The Social Studies Curriculum: Purposes, Problems, and Possibilities, ed. E. Wayne Ross, 265-81. Albany, NY: State University of New York Press.

Fore, Linda C. 1998. "Curriculum Control: Using Discourse and Structure to Manage Educational Reform.” Journal of Curriculum Studies 30: 559-76.

Foucault, Michel. 1991. "Governmentality." In The Foucault Effect: Studies in Governmentality, ed. Graham Burchell, Colin Gordon, and Peter Miller, 87-104. Chicago: University of Chicago Press. 
Gordon, David. 2005. "History Textbooks, Narratives, and Democracy: A Response to Majid Al-Haj." Curriculum Inquiry 35: 367-76.

Grant, S. G. 2001. "An Uncertain Lever: Exploring the Influence of State-Level Testing in New York State on Teaching Social Studies." Teachers College Record 103: $398-426$.

Gutmann, Amy. 1987. Democratic Education. Princeton, NJ: Princeton University Press.

. 2004. "Unity and Diversity in Democratic Multicultural Education: Creative and Destructive Tensions." In Diversity and Citizenship Education: Global Perspectives, ed. James A. Banks, 71-96. New York: Jossey-Bass.

Gutmann, Amy, and David Thompson. 2004. Why Deliberative Democracy? Princeton, NJ: Princeton University Press.

Hart, Daniel, Thomas M. Donnelly, James Youniss, and Robert Atkins. 2007. "High School Community Service as a Predictor of Adult Voting and Volunteering." American Educational Research Journal 44: 197-219.

Hess, Diana E. 2004. "Controversies about Controversial Issues in Democratic Education." PS: Political Science and Politics 37: 257-61.

Hibbing, John R., and Elizabeth Theiss-Morse. 2002. Stealth Democracy: Americans' Beliefs about How Government Should Work. Cambridge, UK: Cambridge University Press.

Hickey, M. Gail. 2002. "Why Did I Get an 'A' in Citizenship? An Ethnographic Study of Emerging Concepts of Citizenship." Journal of Social Studies Research 26 (2): $3-9$.

Hicks, David. 2003. "Thirty Years of Global Education: A Reminder of Key Principles and Precedents." Educational Review 55: 265-75.

Hofman, Amos. 2007. "The Politics of National Education: Values and Aims of Israeli History Curricula, 1956-1995." Journal of Curriculum Studies 39: 441-70.

Holmes, Mark. 2001. "Education and Citizenship in an Age of Pluralism." In Mak ing Good Citizens: Education and Civil Society, ed. Diane Ravitch and Joseph P. Viteritti, 187-212. New Haven, CT: Yale University Press.

Holsti, Ole R. 1969. Content Analysis for the Social Sciences and Humanities. Reading, MA: Addison-Wesley.

Hursh, David. 2007. "Assessing No Child Left Behind and the Rise of Neoliberal Education Policies." American Educational Research Journal 44: 493-518.

Kahne, Joseph, Burnadette Chi, and Ellen Middaugh. 2006. "Building Social Capital for Civic and Political Engagement: The Potential of High School Civics Courses." Canadian Journal of Education 29: 387-409.

Kahne, Joseph, and Susan E. Sporte. 2008. "Developing Citizens: The Impact of Civic Learning Opportunities on Students' Commitment to Civic Participation." American Educational Research Journal 45: 738-66.

Kahne, Joseph, and Joel Westheimer. 2004. "The Limits of Political Efficacy: Educating Citizens for a Democratic Society." PS: Political Science and Politics 37: $289-96$.

2. 2006. "Teaching Democracy: What Schools Need to Do." In The Social Studies Curriculum: Purposes, Problems, Possibilities, ed. E. Wayne Ross, 297-316. Albany, NY: State University of New York Press.

Knight Abowitz, Kathleen, and Jason Harnish. 20o6. "Contemporary Discourses of Citizenship." Review of Educational Research 76: 653-90.

Krippendorff, Klaus. 2004. Content Analysis: An Introduction to Its Methodology. Thousand Oaks, CA: Sage.

Kuklinski, James H., and Paul J. Quirk. 2001. "Conceptual Foundations of Citizen Competence." Political Behavior 23: 285-311.

LaSpina, James Andrew. 2003. "Designing Diversity: Globalization, Textbooks, and the Story of Nations." Journal of Curriculum Studies 35: 667-96.

LeCompte, Margaret D., and Jean J. Schensul. 1999. Analyzing and Interpreting Ethnographic Data. Walnut Creek, CA: AltaMira.

Leming, James S. 2001. "Historical and Ideological Perspectives on Teaching Moral and Civic Virtue." International Journal of Social Education 16 (1): 62-76.

Lopez, Mark Hugo, Emily Kirby, and Jared Sagoff. 2005. “The Youth Vote 2004." The Center for Information and Research on Civic Learning \& Engagement http://www.civicyouth.org/PopUps/FactSheets/FS_Youth_Voting_72-04.pdf.

Macedo, Stephen, Yvette Alex-Assensoh, Jeffrey M. Berry, Michael Brintnall, David E. Campbell, Luis Ricardo Fraga, Archon Fung, et al. 2005. Democracy at Risk: How Political Choices Undermine Citizen Participation and What We Can Do About It. Washington, DC: Brookings Institution.

Martin, Leisa A., and John J. Chiodo. 2007. "Good Citizenship: What Students in Rural Schools Have to Say about It." Theory and Research in Social Education 35: $112-34$.

Merelman, Richard M. 1971. "The Development of Policy Thinking in Adolescents." American Political Science Review 65: 1033-47.
Merryfield, Merry M., and Binaya Subedi. 2006. "Decolonizing the Mind for World-Centered Global Education." In The Social Studies Curriculum: Purposes, Problems, and Possibilities, ed. E. Wayne Ross, 283-295. Albany, NY: State University of New York Press.

Mutz, Diana. 2006. Hearing the Other Side: Deliberative Versus Participatory Democracy. Cambridge, MA: Cambridge University Press.

Myers, John P. 2006. "Rethinking the Social Studies Curriculum in the Context of Globalization: Education for Global Citizenship in the U.S." Theory and Research in Social Education 34: 370-94.

Nash, Margaret A. 2005. "How to Be Thankful for Being Free": Searching for a Convergence of Discourses on Teaching Patriotism, Citizenship, and United States History." Teachers College Record 107: 214-40.

National Commission on Excellence in Education. 1983. A Nation at Risk. http:// www.ed.gov/pubs/NatAtRisk/index.html (accessed June 18, 2009).

Nie, Norman A., Jane Junn, and Kenneth Stehlik-Barry. 1996. Education and Democratic Citizenship in America. Chicago: University of Chicago Press.

Niemi, Richard G., and Jane Junn. 1998. Civic Education: What Makes Students Learn. New Haven, CT: Yale University Press.

Noddings, Nel. 1988. "An Ethic of Caring and Its Implication for Instructional Arrangements." American Journal of Education 96: 215-30.

Parker, Walter C. 2006. "Public Discourses in Schools: Purposes, Problems, Possibilities." Educational Researcher 35 (8): 11-18.

Patrick, John J. 2006. "Content and Process in Education for Democracy." International Journal of Social Education 20 (2): 1-12.

Pike, Mark A. 2007. "The State and Citizenship Education in England: A Curriculum for Subjects or Citizens?" Journal of Curriculum Studies 39: 471-89.

Putnam, Robert D. 200o. Bowling Alone: The Collapse and Revival of American Community. New York: Simon \& Schuster.

Ravitch, Diane. 2006. Should We Teach Patriotism? Phi Delta Kappan 87: 579-81.

Ravitch, Diane, and Chester E. Finn. 1987. What Do Our 17-Year-Olds Know? A Report on the First National Assessment of History and Literature. New York: Harper \& Row.

Ross, E. Wayne. 2006. "The Struggle for the Social Studies Curriculum.” In The Social Studies Curriculum: Purposes, Problems, and Possibilities, ed. E. Wayne Ross, 17-36. Albany, NY: State University of New York Press.

Rugg, Harold O. 1933. The Great Technology: Social Chaos and the Public Mind. New York: John Day.

Sapiro, Virginia. 2004. "Not Your Parents' Political Socialization: Introduction For a New Generation." Annual Review of Political Science 7: 1-23.

Segall, Avner. 2003. “Teachers' Perceptions of the Impact of State-Mandated Standardized Testing: The Michigan Educational Assessment Program (MEAP) as a Case Study of Consequences." Theory and Research in Social Education 31: 287-325.

van Hover, Stephanie D. 2006. “Teaching History in the Old Dominion: The Impact of Virginia's Accountability Reform on Seven Secondary Beginning History Teachers." In Measuring History: Cases of State-Level Testing Across the United States, ed. S. G. Grant, 195-216. Greenwich, CT: Information Age.

van Hover, Stephanie, and Erika Pierce. 2006. “'Next Year Will Be Different': Two First-Year History Teachers' Perceptions of Virginia's Accountability Reform on Their Instructional Decision-Making." Journal of Social Studies Research 30 (2): $38-50$.

Vinson, Kevin D. 2006. "Oppression, Anti-Oppression, and Citizenship Education." In The Social Studies Curriculum: Purposes, Problems, and Possibilities, ed. E. Wayne Ross, 51-75. Albany, NY: State University of New York Press.

Vogler, Kenneth E. 2005. "Impact of a High School Graduation Examination on Social Studies Teachers' Instructional Practices." Journal of Social Studies Research 29 (2): 19-33.

Westheimer, Joel. 2006. "Politics and Patriotism in Education." Phi Delta Kappan 87: 608-20.

2007. Pledging Allegiance: The Politics of Patriotism in America's Schools New York: Teachers College Press.

Westheimer, Joel, and Joseph Kahne. 1998. "Education for Action: Preparing Youth for Participatory Democracy." In Teaching for Social Justice: A Democracy and Education Reader, ed. William Ayers, Jean Ann Hunt, and Therese Quinn, 1-20. New York: Teachers College Press.

- 2004. "What Kind of Citizen? The Politics of Educating for Democracy." American Educational Research Journal 41: 237-69.

Wilen, William W. 2003. "Conducting Effective Issue Based Discussions in Social Studies Classrooms." International Journal of Social Education 18 (1): 99-110.

Young, Iris M. 1992. "Five Faces of Oppression.” In Rethinking Power, ed. Thomas E. Wartenberg, 39-65. Albany, NY: State University of New York Press. 